\title{
The fishes' last stand: the fish fauna of Jiu River Gorge, between decades of coal mining and present day hydroenergetic works
}

\author{
Ilie C. Telcean, Roland E. Mihut \& Diana Cupşa
}

Keywords: mountain river, human impact, colonization, uniformity, mountain species, invasive species

\section{Abstract}

The Jiu River within its gorge was for a long time a river without fish due to pollution from the coal mines in the Petroşani basin, situated upstream. Currently, the river is threatened by the development of hydroenergetic installations, which are projected to reduce the river flow drastically. As a result of the project, less than $10 \%$ of the river flow will remain in the gorge. In the summer of 2015, we studied the composition of the fish fauna in Jiu River Gorge. We found 11 fish species, of which 10 are native to Romania and characteristic for the region and of the habitats studied. Only Lepomis gibbosus is invasive; it was identified in one tributary, with fast flow and rocky substrate, where it was probably introduced. The fish fauna from the Jiu River is uniform due to the region's and river's uniformity. Typically, mountain species are rare and present only in the upstream tributaries. The high anthropogenic influence in the southern part of the gorge, the presence of a less-affected area in its centre, and the mountain species found exclusively in the upstream zones are observed in relation both to fish and to other groups. Despite decades of coal mining pollution, the Jiu River now has a fish fauna that corresponds to the region and its habitats.
Profile

Protected area

Jiu River Gorge

Mountain range

Carpathians

Country

Romania

\section{Introduction}

The Carpathian Mountains are recognized as a refuge area and a speciation centre (Schmitt 2009). Fish species new to science were described recently in this region (Kotlík et al. 2002; Freyhof et al. 2005; Antal et al. 2016). At the same time, important zoo-geographic endemites are known in the area (Bănărescu 1964, 2005; Kottelat \& Freyhof 2007; Telcean et al. 2011). Their presence is important particularly in the context of strong disturbance to freshwater habitats (Saunders et al. 2002; Dudgeon et al. 2006). However, heavily polluted watercourses without fish were found in the region in the past, like the Jiu River downstream of its entrance into the gorge (Bănărescu 1964). Initially, this was a consequence of the coal mining upstream (Ujvári 1972). This industry was well developed and functional for a long time in the upper sector of the Jiu River, in the Petroşani basin (Baron \& Dobre-Baron 2009). However, after 1989 coal mining activity was reduced significantly: between 1989 and 2007, more than $75 \%$ of miners lost their jobs (Monea 2007). This strong reduction of coal mining activity had beneficial effects on the water quality of the Jiu River (Barbu 2008). Thus, in the study carried out at the creation of the Jiu Gorge National Park (NP), 11 fish species were registered (Theme no. 11.RA/2004), of which four were also mentioned in the Natura 2000 site data form (ROSCI0063 standard Natura 2000 data form), a site which overlaps with the park. If in the past the greatest threat for the fish fauna in Jiu River gorge was the upstream mining pollution, there is currently a new threat, represented by a hydroenergetic project which intends to take much of the river water from the gorge (Theme no. 11.RA/2004, S.C. Hidroconstrucția S.A. 2016). The hydroenergetic works (for which the constructions in the field are mostly finished) will affect the entire gorge sector of the Jiu River (Theme no. 11.RA/2004, S.C. Hidroconstrucția S.A. 2016). In the gorge, the medium flow of the river is reported to vary between 20 and $23 \mathrm{~m}^{3} / \mathrm{s}$ (Ujvári 1972) or between 18.81 and $22.28 \mathrm{~m}^{3} / \mathrm{s}$ (Theme no. 11.RA/2004). After the hydroenergetic installations are complete, the river flow in the northern part of the gorge will be only $2.7 \mathrm{~m}^{3} / \mathrm{s}$ (Theme no. 11.RA/2004, S.C. Hidroconstrucția S.A. 2016). From the middle of the gorge onwards, the situation will be even worse, the river flow being reduced to $1 \mathrm{~m}^{3} / \mathrm{s}$ (see Theme no. 11.RA/2004). This study is an indirect consequence of that situation. It started with the park administration's request to know the fish fauna of the Jiu River in the territory covered by the gorge and the park, and it will be the last study of its kind in the Jiu Gorge before the hydroenergetic project is completed.

\section{Material and methods}

The Jiu Gorge NP overlaps with the Jiu River Gorge. It is situated in the Southern Carpathians, between the Vâlcan and Parâng Mountains (Figure 1), in southwestern Romania (Mândruț 2006). The park has no human settlements and is mostly covered by beech forests. The Jiu River cuts through the park from north to south, between the towns of Petroşani and Bumbeşti, and is one of the largest rivers in Romania (Ujvári 1972). The Jiu gorge is approximately $30 \mathrm{~km}$ 


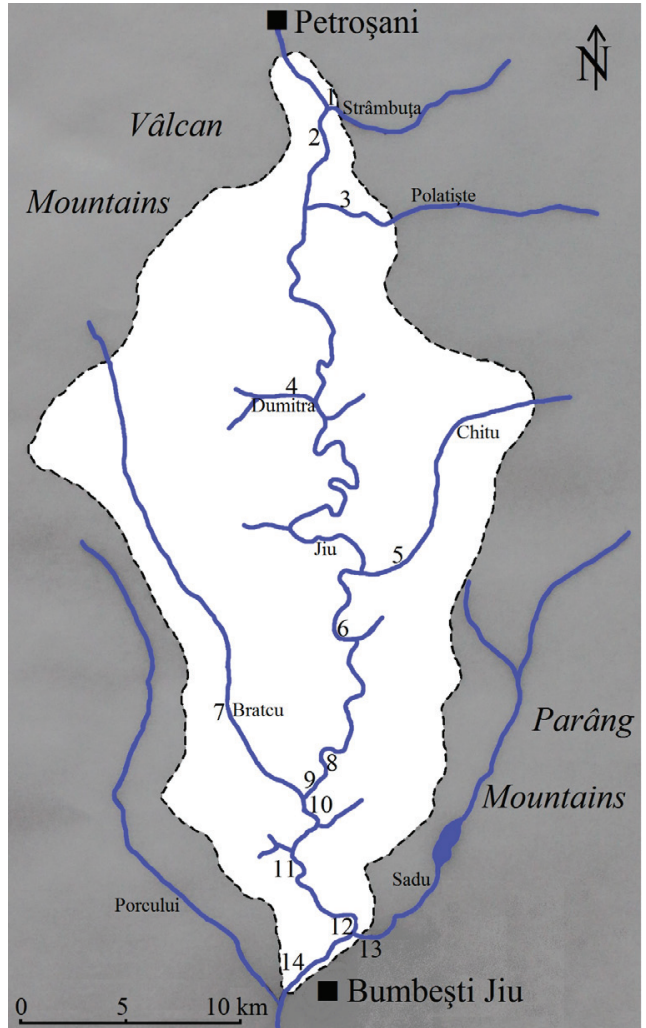

LEGEND

- - - Jiu Gorge National Park limit

rivers

Collecting points:

1. Strâmbuța stream

2. Jiu, Strâmbuța area

3. Polatiște stream

4. Dumitra stream

5. Chitu stream

6. Jiu, Dragalina

7. Bratcu stream

8. Jiu, Meri

9. Jiu, upstream Bratcu

10. Jiu, downstream Bratcu

11. Jiu, upstream Bumbeşti

12. Jiu, upstream Sadu

13. Sadu stream

14. Jiu, downstream Bumbeşti

Figure 1 - The region studied and the sampling points in Jiu Gorge National Park.

long, and various minor tributaries (the Polatiștea, Strâmbuța, Dumitra, Chitul, Bratcu and Sadu) flow into the Jiu within the gorge.

The field research was carried out 5-7 August 2015, at the request of the Jiului Gorge NP's administration, in view of the threat from the hydroenergetic project. Fish were captured by electro narcosis using a HANSGRASSL IG200-2 device. This was operated by one person, sampling sections approximately $100 \mathrm{~m}$ in length. As the research was carried out during the summer, the water level was low. The fish captured were identified in situ and released immediately at the collecting sites. We also analysed various abiotic parameters: $\mathrm{pH}$ value, redox potential, dissolved oxygen, conductivity, dissolved solids and salinity. These were determined using a portable multimeter, type HANNA HI98291-02. The water velocity was measured using a hand-held rod current meter RHCM. We took samples from 14 collecting stations, of which six were situated on the tributaries, and the other eight along the Jiu River (Figure 1).

The data were processed both for total numbers of the various fish species found and in comparative terms, between the Jiu River and its tributaries. We estimated the percentage abundance of the fish both in total and at each site. We also calculated the frequency of occurrence of the species at the collecting points. The diversity was calculated using the Shannon-Weaver index (Shannon \& Weaver 1949), and the similarity between the various sampling sites using the Jaccard index. The significance of the differences was estimated using the Mann Whitney and Kruskal Wallis indices. For statistical analyses, we used the Past.3x software (Hammer et al. 2001).

\section{Results}

We identified 11 fish species in the Jiu River within the Jiu Gorge NP (Table 1). The most frequent was B. petenyi, the Romanian barbel, a species found at 13 collecting points. C. gobio (bullhead) and L. gibbosus (pumpkinseed) registered the lowest frequency of occurrence, each being identified in only 1 station. The highest number of species per collecting point was 5 , a number reached in 4 of the 14 collecting points. At the other extreme is Bratcu stream, a tributary in which we encountered only one species (Table 1). In total, we captured 646 individuals. Most belonged to B. petenyi, which represented $49.53 \%$ of the fish captured in the Jiu River (Table 1). A very low percentage abundance of only $0.30 \%$, was registered for G. gobio and L. gibbosus (Table 1). The percentage abundance differed greatly between the 14 collecting stations. The highest number of fish was captured in the Jiu main course close to the downstream limit of the gorge, and the lowest number in the Bratcu tributary.

The total diversity of the fish assemblages was $\mathrm{H}=2.41$. The diversity differed between stations, the highest being in Strâmbuţa stream $(\mathrm{H}=1.176)$, and the lowest in Bratcu stream $(\mathrm{H}=0)$, a tributary with just one species (Table 1). In terms of the similarity between stations, there are two clusters, one of the sta- 
Table 1 - The percentage abundance, frequency of occurrence and diversity of fish species in the Jiu Gorge NP (Bp - Barbus petenyi, $S c$ - Squalius cephalus, $A b$ - Alburnoides bipunctatus, $G g$ - Gobio gobio, $O b$ - Orthrias barbatulus, StSalmo trutta, $P p$ - Phoxinus phoxinus, $C g$ - Cottus gobio, $S r$-Sabanejewia romanica, $A a-$ Alburnus alburnus, Lg-Lepomis gibbosus).

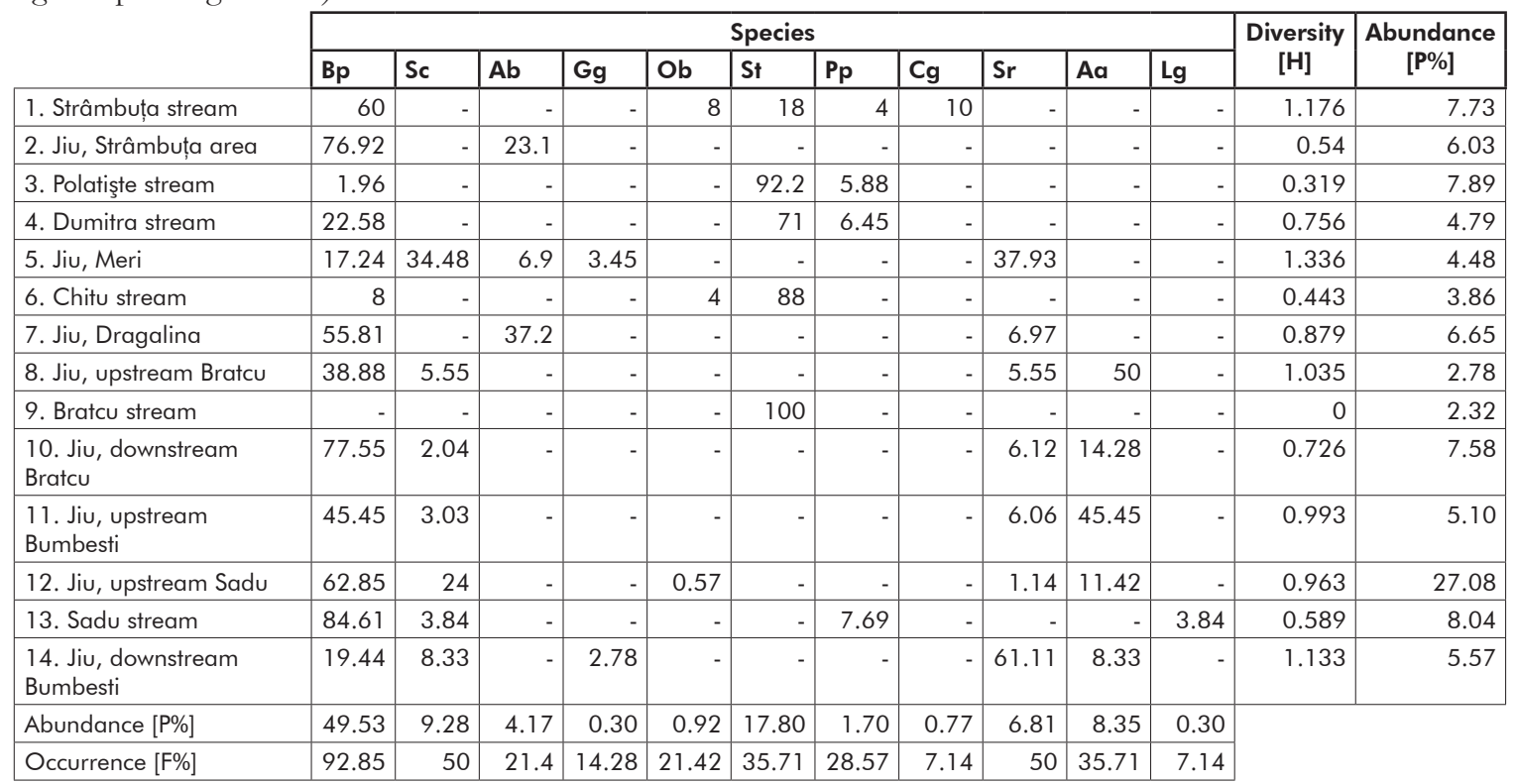

tions along the Jiu and the other of stations along the tributaries (Figure 2). With only one species, Bratcu stream is also in this case the most distinct (Figure 2). In terms of the Jaccard index, the stations from Jiu's main course resemble each other more closely than the stations along the tributaries, but the tributaries also differed among each other. A high overlap $(J=0.8$, $\mathrm{J}=1$ ) was registered between the collecting points from the gorge's downstream sector. The differences between all stations are not statistically significant (Kruskal-Wallis $\mathrm{H}$ test, $\mathrm{p}=0.910$ ). The differences are also not significant when the individual stations are compared with each other using the Mann Whitney test $(p>0.05)$. The same number of species (7) was identified both in the Jiu and in its tributaries. There are species present only in tributaries, others present only in the Jiu's main course (Table 2). According to
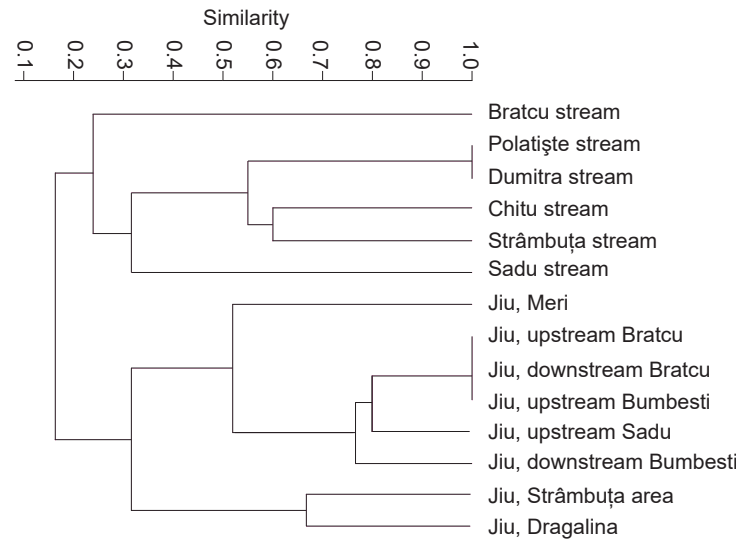

Figure 2 - The similarity between the fish assemblages from different stations. the Jaccard index, the overlap between the fish community from the Jiu's main course and its tributaries is 0.27 . The differences between the tributaries and the river course are not statistically significant (KruskalWallis $\mathrm{H}$ test $\mathrm{p}=0.866$, Mann Whitney $\mathrm{p}=0.892$ ).

There was no linear relationship between the number of individuals and the abiotic parameters analysed ( $\mathrm{r}$ between -0.134 and +0.096$)$. The redox potential influenced both the species number $(\mathrm{r}=-0.584)$ and their diversity $(r=-0.741)$. The water speed did not affect the species number, but a positive linear relationship was registered between the species number and the water speed $(\mathrm{r}=+0.619)$. Numbers and diversity of $B$. petenyi (Romanian barbel), S. cephalus (chub), $A$. bipunctatus (schneider), $A$. alburnus (bleak) did not show any relation to the parameters analysed. For G. gobio (gudgeon), the individual number was influenced negatively by the water redox potential $(r=-0.655)$. The number of $O$. barbatulus (stone loach) was influenced negatively by the water conductivity $(\mathrm{r}=-0.586)$, by the solid substances dissolved in the water $(\mathrm{r}=-0.558)$, and by the salinity $(\mathrm{r}=-0.543) . S$. trutta (brown trout) showed a strong negative relation with the water temperature $(\mathrm{r}=-0.774)$, a moderate positive relation with the water redox potential $(\mathrm{r}=+0.518)$ and with the quantity of oxygen dissolved in the water $(\mathrm{r}=+0.686)$, and a moderate negative relation with the water $\mathrm{pH}(\mathrm{r}=-0.494)$. Individual numbers of $P$. phoxinus (Eurasian minnow) showed a negative relation with the conductivity $(\mathrm{r}=-0.568), \mathrm{pH}(\mathrm{r}=-0.538)$, dissolved solid substances $(\mathrm{r}=-0.536)$, salinity $(\mathrm{r}=-0.581)$, and water temperature $(\mathrm{r}=-0.533)$. C. gobio numbers were negatively influenced by the water conductivity $(\mathrm{r}=-0.547)$, dissolved solid substances 
Table 2 - The percentage abundance, and frequency of occurrence of fish species in the Jiu River and in its tributaries. (Bp - Barbus petenyi, $S c$ - Squalius cephalus, $A b$ - Alburnoides bipunctatus, $G g$ - Gobio gobio, $O b$ - Orthrias barbatulus, $S t$ - Salmo trutta, $P p$ - Phoxinus phoxinus, $C g$ - Cottus gobio, $S r$-Sabanejewia romanica, $A a$ - Alburnus alburnus, Lg - Lepomis gibbosus),

\begin{tabular}{|c|c|c|c|c|c|c|c|c|c|c|c|c|}
\hline & \multicolumn{11}{|c|}{ Species } \\
\hline & & Bp & Sc & $A b$ & Gg & $\mathrm{Ob}$ & St & $\mathrm{Pp}$ & $\mathrm{Cg}$ & $\mathrm{Sr}$ & $\mathbf{A a}$ & $\mathrm{Lg}$ \\
\hline \multirow{2}{*}{ Jiu main course } & Abundance [P\%] & 55.92 & 13.74 & 6.39 & 0.47 & 0.23 & - & - & - & 10.42 & 12.79 & - \\
\hline & Occurrence [F\%] & 100 & 75 & 37.5 & 25 & 12.5 & - & - & - & 87.5 & 62.5 & - \\
\hline \multirow{2}{*}{ Tributaries } & Abundance [P\%] & 37.5 & 0.89 & - & - & 2.23 & 51.33 & 4.91 & 2.23 & - & - & 0.89 \\
\hline & Occurrence [F\%] & 83.33 & 16.66 & - & - & 33.33 & 83.33 & 66.66 & 16.66 & - & - & 16.66 \\
\hline
\end{tabular}

$(\mathrm{r}=-0.514)$, and water salinity $(\mathrm{r}=-0.507)$. S. romanica (Romanian loach) showed a positive relation with $\mathrm{pH}$ $(\mathrm{r}=+0.546)$, conductivity $(\mathrm{r}=+0.526)$, and water temperature $(\mathrm{r}=+0.551)$. This species had a negative relation with the redox potential $(\mathrm{r}=-0.618)$, and with the dissolved oxygen $(\mathrm{r}=-0.514)$. B. petenyi, $S$. cephalus and A. alburnus showed a moderate positive relation with the water speed $(\mathrm{r}=+0.644, \mathrm{r}=+0.670, \mathrm{r}=+0.526)$, and $S$. romanica a moderate negative relation with the water speed $(\mathrm{r}=-0.448)$.

\section{DISCUSSION}

In terms of composition and number of species, the fish fauna from the Jiu Gorge resembles those recorded in other rivers of the Southern Carpathians (Ureche et al. 2007; Bănăduc et al. 2013a, b). With one exception, the fish species from the Jiu River are the ones expected to be present, having ecological requirements that coincide with the characteristics of the river and region, and the altitude. They are species that are well represented in Romania, characteristic of mountains and hills (Bănărescu 1964). The exception is $L$. gibbosus, a species associated with stagnant waters from lowlands (Bănărescu 1964). L. gibbosus is the only non-native species (Bănărescu 1964).

Although 11 species seems a low number, more than 60 years ago the Jiu River was considered a river without fish throughout the gorge, the only records being from the tributaries (Bănărescu 1964). In the mid-1990s, the river was still a polluted one, with black water (personal observations). Between 2002 and 2005 , the mineral suspension in the river was reduced from $64000 \mathrm{mg} / 1$ to less than $100 \mathrm{mg} / 1$ (Murărița et al. 2008). Thus, in less than 20 years since the reduction in pollution, the fish fauna in the Jiu River has recovered concerning both species and numbers of individuals. Because almost all species were present in the region, the river must have been recolonized by the fish species from the tributaries in the gorge, from upstream of the affected sector, and also probably from downstream sectors. Species associated with low altitude areas and slow-flowing waters, like G. gobio (Bănărescu 1964), which has been recorded in waters of flat areas (Bănărescu 1964; Costiniuc et al. 2007; Bănăduc et al. 2013a; Telcean et al. 2014), have probably travelled upstream. The rapid colonization proves that even during the most-polluted period small populations had remained in the region, little affected by the pollution, and able in a short period to fill the geographic and population gaps. Fish assemblages seem able to recover relatively rapidly after periods of catastrophic pollution, if there are colonization sources (Antal et al. 2013; De Miguel et al. 2014, 2015, 2016). Even if the effect of pollution can be very harsh, it can nevertheless be transitory: although the impact on the Jiu River lasted several decades, the Jiu is a river with fish again. The improvement in water quality has led to an increase of fish species numbers in other rivers as well (Azimi \& Rocher 2016; Kruk et al. 2016).

The recovery of the Jiu River fish fauna probably took less than 10 years, although in large degraded rivers the recovery of the fish fauna required 10-20 years (Kruk et al. 2016). In 2003, in the study regarding the establishment of the Jiu Gorge NP, 11 fish species were mentioned (Theme no. 11.RA/2004), exactly the same number as we found in 2015. Although the number is the same, the species are not entirely the same. The differences between the species recorded in the previous studies (Theme no. 11.RA/2004, ROSCI0063 standard Natura 2000 data form) and the ones that we encountered are probably accidental. Thus, the absence in our study of the previously mentioned G. uranoscopus (Bănărescu 1964; ROSCI0063 standard Natura 2000 data form) has no apparent reason.

One species recorded for the first time in the Jiu Gorge, L. gibbosus, is non-native and invasive in Romania (Bănărescu 1964). It was previously mentioned in the Jiu's lower sector, in artificial lakes (Dumitraşcu \& Mitrea 2012). Those habitats correspond with the requirements of $L$. gibbosus, a species frequently found in stagnant waters in plain areas (Bănărescu 1964; Imecs \& Nagy 2013; Telcean et al. 2014). Although the characteristics of the Sadu tributary are contrary to the requirements of $L$. gibbosus, this species is extremely adaptable, having been recorded in other atypical habitats (Śumer et al. 2005; Sas-Kovács et al. 2015). Its presence in Sadu is difficult to explain. The tributary is characterized by a fast flow and rocky substratum, and L. gibbosus was not encountered in Jiu's main course downstream of the confluence of the Sadu with the Jiu. Because the localities in the Jiu where the species have been mentioned (Dumitraşcu \& Mitrea 2012) are situated downstream, in other types of habitats, and 
because between these locations and the Sadu the river is unfavourable to the species, we concluded that $L$. gibbosus did not reach Sadu by moving upstream in the Jiu on its own. It was probably introduced by humans for fishing purposes, in a small dam lake upstream on the Sadu tributary, from where it escapes into the stream. In other regions as well, isolated populations of L. gibbosus have been identified near human settlements (van Kleef et al. 2008). In Romania, a similar case was recorded for another invasive species, Pseudorasbora parva (Telcean et al. 2015). The presence of L. gibbosus in new regions was explained in other cases by its introduction by fishermen (Oliva-Paterna et al. 2005). Its further upstream distribution in the Jiu River is improbable, because of the contradiction between its demands and the river's characteristics. The presence of L. gibbosus in the Sadu is due to the higher human impact in the southern sector of the Jiu Gorge, a fact also observed in some terrestrial animals (Covaciu-Marcov et al. 2009; Tomescu et al. 2011).

The composition of the Jiu river fish fauna is a result of the gorge's uniformity. The altitude differences are small; the river has a fast flow and stony substratum, and is surrounded by forests. The uniformity of the habitats has determined the uniformity of the fish fauna. Even if the fish fauna from the Jiu gorge comprise hilly and mountain species, those species which are typically mountain species are very rare and have retreated to the upper sector and the tributaries. This is the case of C. gobio, a species present only in cold mountain waters (Bănărescu 1964). We identified it only in Strâmbuța tributary in the upper sector of the gorge. Only a short segment of the tributary is located in the park, and the population is very small. It is possible that because of the high summer temperatures at the time of our survey, C. gobio had ascended into the coldest tributary, being influenced in the first place by thermal conditions and preferring small, clear streams (Legalle et al. 2005). Nevertheless, C. gobio is a strictly sedentary species (Bănărescu 1964). It has low dispersal capabilities, being stopped even by small barriers (Utzinger et al. 1998). It is strongly influenced by the amount of shelter available (Vlach et al. 2005). Thus, in the gorge the fish distribution resembles that of the distribution of herpetofauna, where the typical mountain species are very rare, present only in the highest sections of the gorge (Covaciu-Marcov et al. 2009). The differences between the fish fauna of the Jiu and those of its tributaries are small, mainly because the river was colonized from its tributaries. Only those species strongly related with cold water, like C. gobio, did not leave the tributaries and did not colonize the river's main course. Because of the more intense human impact on the lower part of the gorge, the middle and upper sections have a higher conservation value, a fact previously observed in the case of herpetofauna (Covaciu-Marcov et al. 2009).

The fish are not the most important group in Jiu Gorge NP; other vertebrates, like the herpetofauna, having more protected species in the park (CovaciuMarcov et al. 2009). Nevertheless, in the park there are species with high conservation importance, like C. gobio (O.U.G 57/2007), but also species endemic to Romania, like S. romanica (Bănărescu 1964). The presence of this species is important for the protected area, $S$. romanica having a limited distribution range (Bănărescu 1964, 1998; 2005). Jiu Gorge is situated inside the species distribution range, $S$. romanica being recorded in neighbouring rivers (Bănăduc et al. 2013b).

The fish fauna from the Jiu prove that they can recover rapidly, even after a long period of human impact, forming stable assemblages that are characteristic for the region. After the cessation of mining activities, the fish fauna recovered to levels that could be expected, from the other unpolluted waters of the region. In the future, human impact will affect specifically the waters of the region: the hydroenergetic works will lead to the drastic reduction of the river flow, affecting not only the fish fauna but the region as a whole. The maintenance of a natural hydrologic regime and the integrity of the hydrographic network are considered essential for freshwater protected areas (Saunders et al. 2002). But the hydroenergetic works on the Jiu River will drastically alter the river flow. There are many consequences for biodiversity of a modified flow regime (Bunn \& Arthington 2002). Unfortunately, in the Jiu Gorge changes cannot be considered minor: a flow reduction of more then $90 \%$ along the entire length of the gorge will be implemented (Theme no. 11.RA/2004, S.C. Hidroconstrucția S.A. 2016). In the water remaining in the Gorge, we can hardly consider that real fish communities will survive. Furthermore, the upstream populations will be isolated. And yet in other countries, fish-friendly solutions are implemented at new hydroelectric stations (Larinier 2008). Unfortunately, in Romania other hydroenergetic projects led to the disappearance of one of only three known populations of the endemic Romanichthys valsanicola in 1965, when as a result of the construction of the Vidraru dam, the Argeş River remained without water (Bănărescu et al. 1995). Although such rare species are not present in the Jiu River, the Jiu Gorge is a NP, in which the history of 1965 should not be repeated.

\section{References}

Antal, L., B. Halasi-Kovács \& S.A. Nagy 2013. Changes in fish assemblage in the Hungarian section of River Szamos / Somess after a massive cyanide and heavy metal pollution. North-Western Journal of Zoology 9(1): 131-138.

Antal, L., B. László, P. Kotlík, A. Moszár, I. Czeglédi, M. Oldal, G. Kemenesi, F. Jakab \& S.A. Nagy 2016. Phylogenetic evidence for a new species of Barbus in the Danube River basin. Molecular Phylogenetics and Evolution 96: 187-194.

Azimi, S. \& V. Rocher. 2016. Influence of the water quality improvement of fish population in the Seine 
River (Paris, France) over the 1990-2013 period. Science of the Total Environment 542: 955-964.

Barbu, C. 2008. The effects of the mining activity over the waters from Jiu valley. Journal of Applied Economic Sciences 4(6): 374-381.

Baron, M. \& O. Dobre-Baron 2009. The emergence of the Jiu Valley coal basin (Romania) - a consequence of the industrial revolution. Annals of the University of Petrosani, Economics 9(3): 53-80.

Bănăduc, D., V. Stroilă \& A. Curtean-Bănăduc 2013a. The fish fauna of the Timiș River (Banat, Romania). Transylvanian Review of Systematical and Ecological Research 15 (special issue "The Timiş River Basin"): 145-172.

Bănăduc, D., M. Mărginean \& A. Curtean-Bănăduc 2013b. Geographical and human impact elements influence on the fish fauna of the Olteț River (Romania). Transylvanian Review of Systematical and Ecological Research 15(2): 9-44.

Bănărescu, P. 1964. Fauna R.P.R., vol. 13. Pisces-Osteichthyes. [In Romanian]

Bănărescu, P. 1998. On the relations between hydrography and the ranges of freshwater fish species and subspecies. Italian Journal of Zoology 65 (Suppl.): 87-93.

Bănărescu, P. 2005. Pisces (Pești). In: Botnariuc, N. \& V. Tatole (eds.), Cartea Rosie a Vertebratelor din România. Bucharest. [In Romanian]

Bănărescu, P., R. Bless \& A. Georgescu 1995. Threatened fishes of the World: Romanichthys valsanicola Dumitrescu, Bănărescu and Stoica, 1957 (Percidae). Environmental Biology of Fishes 43: 144.

Bunn, S.E. \& A.H. Arthington 2002. Basic principles and ecological consequences of altered flow regimes for aquatic biodiversity. Environmental Management 30(4): 492-507.

Costiniuc, C.D., G. Davideanu \& A. Davideanu 2007. Data concerning the fish communities of the Baseu River (Romania). Analele Ştiințifice ale Universităţii "Al. I. Cuza" Iassi, s. Biologie animală, 53: 59-66.

Covaciu-Marcov, S.-D., A.S. Cicort-Lucaciu, F. Dobre, S. Ferenți, M. Birceanu, R. Mihuț \& A. Strugariu 2009. The herpetofauna of the Jiului Gorge National Park, Romania. North-Western Journal of Zoology 5(1): S1-S78.

de Miguel, R.J., F.J. Oliva-Paterna, L. Gálvez-Bravo \& C. Fernández-Delgado 2014. Fish composition in the Guadiamar River basin after one of the worst mining spills in Europe. Limnetica 33(2): 375-384.

de Miguel, R.J., L. Gálvez-Bravo, F.J. Oliva-Paterna, L. Cayuela \& C. Fernández-Delgado 2015. Recolonization Process and Fish Assemblage Dynamics in the Guadiamar River (SW Spain). After the Aznalcóllar Mine Toxic Spill. River Research and Applications, doi 10.1002 / rra.2944

de Miguel, R.J., L. Gálvez-Bravo, F.J. Oliva-Paterna \& C. Fernández-Delgado 2016. Disturbance accumulation hampers fish assemblage recovery long after the worst mining spill in the Iberian Peninsula. Journal of Applied Ichthyology 32: 180-189.

Dumitraşcu, O.C. \& I. Mitrea 2012. Data upon the ichthyofauna of three reservoirs from Jiu River, Romania. South Western Journal of Horticulture, Biology and Environment 3(1): 1-8.

Dudgeon, D., A.H. Arthington, M.O. Gessner, Z. Kawataba, D.J. Knowler, C. Lévêque, R.J. Naiman, A.H. Prieur-Richard, D. Soto, M.L.J. Stiassny \& C.A. Sullivan 2006. Freshwater biodiversity: importance, threats, status and conservation challenges. Biological Reviews 81: 163-182.

Freyhof, J., M. Kottelat \& A. Nolte 2005. Taxonomic diversity of European Cottus with description of eight new species (Teleostei: Cottidae). Ichthyological Exploration of Freshwaters 16(2): 107-172.

Hammer, Ø., D.A.T. Harper \& P.D. Ryan 2001. PAST: Paleontological statistics software package for education and data analysis. Palaeontologia Electronica 4(1): 9 .

Imecs, I. \& A.-A. Nagy 2013. Data concerning the fish fauna of the ROSCI0224 Scroviştea Natura 2000 Site (Romania) and management measure proposals. Romanian Journal of Biology - Zoology 58(2): 101-114.

Kottelat, M. \& J. Freyhof 2007. Handbook of European freshwater fishes. Kottelat, Cornol, Switzerland and Freyhof, Berlin, Germany.

Kotlík, P., C.S. Tsigenopoulos, P. Ráb \& P. Berrebi 2002. Two new Barbus species from the Danube River basin, with redescription of B. petenyi (Teleostei: Cyprinidae). Folia Zoologica 51(3): 227-240.

Kruk, A., M. Ciepłucha, G. Zięba, S. Tybulczuk, M. Tszydel, L. Marszał, D. Błońska, W. Galicka \& M. Przybylski 2016. Recovery of the fish fauna in the upper Warta River, Poland: Long term (1963-2012) monitoring study. Ecological Informatics 33: 109-118.

Larinier, M. 2008. Fish passage experience at smallscale hydro-electric power plants in France. Hydrobiologia 609: 97-108.

Legalle, M., F. Santoul, J. Figuerola, S. Mastrorillo \& R. Céréghino 2005. Factors influencing the spatial distribution patterns of the bullhead (Cottus gobio L., Teleostei Cottidae): a multi-scale study. Biodiversity and Conservation 14: 1319-1334.

Mândrut,, O. 2006. Mic Atlas de Geografie a României. Ed. Corint, Bucharest. [In Romanian]

Monea, M. 2007. The economical effects of mining activity restructuring in Jiu valley. Annals of the University of Petrosani, Economics 7: 243-248.

Murărița, I., D. Ciupeanu \& O. Țucă 2008. The Jiu valley hollow environment - problem of the sustainable development. Bulletin UASVM, Agriculture 65(2): 29-38.

Oliva-Paterna, F.J., A. Andreu, D. Verdiell \& M. Torralva 2005. First occurrence of Lepomis gibbosus (L., 1758) in Segura river basin (SE, Spain). Limnetica 24(34): 199-202. 
Saunders, D.L., J.J. Meeuwig \& C.J. Vincent 2002. Freshwater Protected Areas: Strategies for Conservation. Conservation Biology 16(1): 30-41.

Sas-Kovács, I., I.C. Telcean \& S.-D. Covaciu-Marcov 2015. A non-native fish assemblage in geothermal waters of Romania. Journal of Applied Ichthyology 31: 211-215.

Schmitt, T. 2009. Biogeographical and evolutionary importance of the European mountain systems. Frontiers in Zoology 6:9. doi:10.1186/1742-9994-6-9.

Shannon, C.E. \& W. Weaver 1949. The mathematical theory of communication. Urbana.

Śumer, S., V. Kovác, M. Povź \& M. Slatner 2005. External morphology of a Slovenian population of pumpkinseed Lepomis gibbosus (L.) from a habitat with extreme thermal conditions. Journal of Applied Ichtbyology 21: 306-311.

Telcean, I.C., A.S. Cicort-Lucaciu, I. Sas \& S.-D. Covaciu-Marcov 2011. Romanichthys valsanicola is still fighting! How can we help? North-Western Journal of Zoology 7(2): 334-338.

Telcean, I.C., D. Cupşa, I. Sas-Kovacs, A.S. CicortLucaciu \& S.-D. Covaciu-Marcov 2014. Some data upon the fish fauna from Carei Plain natural protected area obtained with herpetological methods. NorthWestern Journal of Zoology, 10(Supplement1): S135S140.

Telcean, I.C., I. Sas-Kovács \& S.-D. Covaciu-Marcov 2015. Unusual altitude and habitat for the invasive fish Pseudorasbora parva in the Vâlsan river basin, Romania. Oltenia, Studii și Comunicări, științele Naturii, 31(1): 237-240.

Tomescu, N., S. Ferenți, L.A. Teodor, S.-D. Covaciu-Marcov, A.S. Cicort-Lucaciu \& F.N. Sucea 2011 Terrestrial Isopods (Isopoda: Oniscoidaea) from Jiului Gorge National Park, Romania. North-Western Journal of Zoology 7(2): 277-285.

Ujvári, I. 1972. Geografia apelor României. Editura Ştiințifică, Bucureşti. [In Romanian]

Ureche, D., K.W. Battes \& I. Stoica 2007. Ichthyofauna actual state in the upper and mid course of the river Argeş hydrographical basin. Analele Ştiintififice ale Universitatii "Alexandru Ioan Cuqa" Iassi, sectia Biologie animală 53: 73-82.

Utzinger, J., C. Roth \& A. Peter 1998. Effects of environmental parameters on the distribution of bullhead Cottus gobio with particular consideration of the effects of obstructions. Journal of Applied Ecology 35: 882-892.

Van Kleef, H., G. Van Der Velde, R.S.E.W. Leuven \& H. Esselink 2008. Pumpkinseed sunfish (Lepomis gibbosus) invasions facilitated by introductions and nature management strongly reduce macroinvertebrate abundance in isolated water bodies. Biological Invasions 10: 1481-1490.

Vlach, P., J. Dušek, M. Švátora \& P. Moravec 2005. Fish assemblage structure, habitat and microhabitat preference of five fish species in a small stream. Folia Zoologica 54(4): 421-431.

\section{Relevant Romanian Acts}

ROSCI0063, Formularul Standard Natura 2000. Monitorul Oficial al României, Partea I, Nr. 98 bis/7. II.2008. [In Romanian]

O.U.G. 57 / 2007 privind regimul ariilor naturale protejate, conservarea habitatelor naturale, a florei şi faunei sălbatice. [In Romanian]

Theme no. 11.RA/2004: Studiu privind constituirea Parcului National "Defileul Jiului". Institutul de Cercetări şi Amenajări Silvice Bunureşti. [In Romanian]

S.C. Hidroconstrucția S.A. 2016. Amenajarea hidroenergetică a râului Jiu pe sectorul Livezeni Bumbeşti. Revista Construcțiilor, 12 (122): 6-7. [In Romanian]

\section{Authors}

\section{Ilie C. Telcean}

is Associate Professor of Hydrobiology. His main research activity is in the field of ichthyology. He is involved in research into the fish fauna of the main rivers of western Romania, fish diets and invasive freshwater fish species. University of Oradea, Faculty of Sciences, Department of Biology; 1, Universității, Oradea 410087, Romania.

\section{Roland E. Mihut}

is a ranger at Jiu Gorge National Park, where he is involved in many activities. He has good knowledge of the biodiversity of the park and the distributions of the main protected species. Jiu Gorge National Park, Str. Lt. Col. Dumitru Petrescu, Nr.3, Târgu-Jiu, Romania.

\section{Diana Cupşa}

is Professor of Invertebrate Zoology. Her main research activity focuses on macrozoobenthic invertebrate communities from freshwaters, invasive freshwater invertebrates within Romanian territory, and the diets of Romanian freshwater fish and aquatic herpetofauna. University of Oradea, Faculty of Sciences, Department of Biology; 1, Universității, Oradea 410087, Romania. E-mail: cupsa2007@yahoo.com 